\title{
Effects of intraspecific competition and scavenging on growth of the periwinkle Littorina littorea
}

\author{
Peter S. Petraitis* \\ Department of Biology, University of Pennsylvania, Philadelphia, Pennsylvania 19104-6018, USA
}

\begin{abstract}
The effects of density of conspecifics, size of experimental cages, and scavenging of animal tissue on the growth rate of Littorina littorea (L.) were tested during the summers of 1991, 1992, and 1994. In 1991, the effects of intraspecific competition were examined by holding individually marked periwinkles in cages of 5 different sizes and at 4 densities. Cages were 25, 50, 100, 200, and $400 \mathrm{~cm}^{2}$ in area, and were of different sizes to test for caging artifacts. Experimental densities were $50,100,200$, and $400 \mathrm{~m}^{-2}$ and encompassed normal field densities $\left(\bar{x}=299 \mathrm{~m}^{-2}\right.$; SD $\left.=205\right)$. Growth was measured as final shell height and the amount of shell added at the lip of the aperture. The experiment showed evidence for intraspecific competition and no effect of cage size. Periwinkles, which were between 12 and $16 \mathrm{~mm}$ in shell height, added an average of $6.8 \mathrm{~mm}$ per 6 wk at the lip when held at a density of $50 \mathrm{~m}^{-2}$ and $1.6 \mathrm{~mm}$ per $6 \mathrm{wk}$ when held at $400 \mathrm{~m}^{-2}$. The results were confirmed with a 1992 experiment, which used $100 \mathrm{~cm}^{2}$ cages and densities of 100, 200, and $400 \mathrm{~m}^{-2}$. Field observations suggested that $L$. littorea may also scavenge animal tissue, and this was tested in a 1994 experiment in which periwinkles were provided mussel (Mytilus edulis) tissue. Growth rates were nearly doubled when snails were given mussel tissue. While L. littorea is one of the most studied gastropods, this study is the first experimental test of intraspecific competition, and the first demonstration that scavenging can enhance growth rates of periwinkles.
\end{abstract}

KEY WORDS: Intraspecific competition · Littorina $\cdot$ Growth rates · Mytilus · Gastropods · Field experiments

\section{INTRODUCTION}

Benthic grazers are a ubiquitous feature of rocky intertidal shores, and the interactions among grazers play a major role in structuring marine communities (Haven 1973, Underwood 1980, Underwood \& Jernakoff 1981, Creese \& Underwood 1982, Ortega 1985, Petraitis 1990, Schmitt 1996). Competitive interactions among marine grazers have been widely studied (Underwood 1976, 1978, 1984a,b, Branch \& Branch 1981, Branch 1984, Quinn \& Ryan 1989) and, in general, intraspecific competition among marine grazers tends to show a more profound effect than interspecific competition (see Table 2 in Gurevitch et al. 1992). Given the ease of manipulating marine benthic graz-

*E-mail: ppetrait@sas.upenn.edu ers, it is not surprising that many of the experimental tests of competition among herbivores come from the marine literature. For example, $76 \%$ of the experiments in Gurevitch et al.'s meta-analysis of the effects of competition among herbivores were from marine systems. What is surprising is how little experimental work has been done on competitive interactions involving Littorina littorea (L.).

The periwinkle Littorina littorea is one of the most important invertebrate grazers on the eastern shores of North America. It is found in a variety of habitats, ranging from the cobble beaches of sheltered bays to the rocky shores on exposed coasts. Densities range from 2 to $4276 \mathrm{~m}^{-2}$, and L. littorea's effect on community structure is profound (see McQuaid 1996). For example, L. littorea has been shown to affect species diversity (Lubchenco 1978), algal abundance (Lubchenco 1978, Petraitis 1983), growth and behavior of other gastro- 
pods (Brenchley \& Carlton 1983, Petraitis 1989), and recruitment of sessile invertebrates (Petraitis 1983, 1987, 1990).

Despite the amount of research that has been done on the community-level effects of Littorina littorea, there has not been a single study of the intraspecific effects on the growth rate of periwinkles. There have been a number of studies of growth in L. littorea (e.g. Hayes 1929, Moore 1937, Williams 1964, Fish 1972, Chase \& Thomas 1998), but none have directly addressed intraspecific effects of density on growth. Moreover, there have been remarkably few field studies of growth of individually marked L. littorea (Ekaratne \& Crisp 1984, Behrens Yamada 1987, Gardner \& Thomas 1987). Most of the studies (Hayes 1929, Moore 1937, Williams 1964, Fish 1972, Chase \& Thomas 1998) have used cohort averages to estimate rates of growth. Williams (1964) and Fish (1972) sampled populations several times and provided data on changes in average shell height over time. Other studies (Williams 1964, Chase \& Thomas 1998) have used size-frequency distributions to infer average growth rates.

Here I report the first experimental study of the intraspecific effects of density on the growth rate of Littorina littorea under field conditions using individually marked snails. Experiments were undertaken in 1991 and 1992 to test the effect of intraspecific competition on growth and the repeatability of results from year to year (see Connell 1983, Underwood 1986 for discussion of the need to repeat studies over time). The first experiment included cages of different sizes because consumption rates of foragers and renewal rates of resources can vary with cage size (Quinn \& Keough 1993, Mac Nally 1997), and it is possible that the observed effects of intraspecific competition on growth rates may show a cage artifact.

In the course of the first 2 experiments, it was noticed that Littorina littorea appeared to scavenge on dead invertebrates (P. G. Fairweather pers. comm.), and thus growth rate of $L$. littorea may depend not only on the availability of algal resources but also on the remains of other invertebrates. Scavenging by $L$. littorea has been reported elsewhere (Hayes 1929, Fenske 1997), but the benefits of scavenging were not known. Thus, a third experiment was undertaken to examine if growth rates of $L$. littorea could be altered by supplementing the diet with animal tissue.

\section{MATERIALS AND METHODS}

Study site. Observations and experiments were done on the low shore in Mackerel Cove on Swan's
Island, Maine, USA $\left(44^{\circ} 10^{\prime} \mathrm{N}, 68^{\circ} 25^{\prime} \mathrm{W}\right)$. The site has been described in Petraitis $(1987,1991)$. Briefly, the shore is a mixture of granite and basalt bedrock and cobbles. The collection of snails for the experiments, sampling, and the experiments themselves were done on the shore between $0.0 \mathrm{~m}$ and $+0.5 \mathrm{~m}$ mean low water. This is below the midzone algal belt that is dominated by Ascophyllum nodosum (L.) Le Jolis. The most common sessile organisms on the study site were Mytilus edulis L. and Semibalanus balanoides (L.), which covered less than $30 \%$ of the surface. Macroalgae were rare. The snails Littorina littorea and Nucella lapillus (L.) were the most common mobile species.

Field observations. Data on density of periwinkles at Mackerel Cove were collected on 2 August 1992. Sampling was done using a $50 \times 50 \mathrm{~cm}$ quadrat divided into $10 \times 10 \mathrm{~cm}$ squares. The position of the quadrat was determined by tossing it in a haphazard fashion. This was done 10 times in areas of bedrock and 10 times in areas of cobbles. In each quadrat, the numbers of periwinkles in five $10 \times 10 \mathrm{~cm}$ squares were counted (the square in the center of the quadrat and the 4 squares in the corners). Data were analyzed as a nested analysis of variance with the 5 squares per quadrat nested within quadrats and the quadrats nested within type of surface. Data did not require transformation, and analysis was based on numbers per $100 \mathrm{~cm}^{2}$. Densities are reported as numbers per $\mathrm{m}^{2}$.

Cage design, marking and measurement of snails, and data presentation. The cages were modified versions of the $45 \times 50 \mathrm{~cm}$ basket cages used by Petraitis (1989). These baskets were constructed by folding in half a $90 \times 50 \mathrm{~cm}$ sheet of stainless steel mesh (mesh size approx. $5 \times 5 \mathrm{~mm}$ ) and tying 2 edges shut to form a pouch-like basket. Granite blocks (approx. $5 \times 25 \times$ $25 \mathrm{~cm}$ ) were used as the experimental surfaces. The blocks were from an abandoned quarry on the island, and the granite is common throughout the intertidal zone. The blocks had been used in previous studies and had been in the intertidal zone for at least $1 \mathrm{yr}$. Stainless steel mesh cylinders were used to close off specific areas on each block. A cylinder, about $2 \mathrm{~cm}$ high, was attached to the granite block with stainless steel wire. The granite block with the attached cylinder was then placed in a basket. Snails were placed inside the cylinder, and the basket was wired shut with the cylinder held tightly between the granite and the top of the basket.

Shell height was measured to the nearest $0.1 \mathrm{~mm}$ with dial calipers. Vermeij (1980) suggested that growth of the shell lip was a better measure of growth than changes in shell height, so the edge of the lip of each periwinkle was also painted with fin- 
gernail polish to serve as a benchmark of lip growth. Growth at the lip was measured to the nearest $0.1 \mathrm{~mm}$ as the distance from the paint mark to the edge of the lip along the suture line of the body whorl. Each snail received an identification number in permanent ink.

For data presentation (but not for analyses), growth rates were standardized to the amount of growth per 6 wk because the experiments differed in duration: $6 \mathrm{wk}$ is slightly less than the geometric mean of the duration of the 3 experiments presented here. Earlier studies of Littorina littorea growth expressed growth as change $\mathrm{d}^{-1}$. However, my analysis of data from Gardner \& Thomas (1987; their Table 3) for L. littorea showed a significant negative correlation between the natural log of the rate of growth and the number of days which the experiment ran $(\mathrm{r}=-0.75 ; \mathrm{n}=8 ; \mathrm{p} \leq$ 0.05 for growth at the aperture lip). This suggested that growth should be expressed as the rate per experiment duration.

1991 competition experiment. The effects of density and cage size on growth of Littorina littorea were analyzed using a factorial design in which the total area per cage and the density per cage were manipulated separately. Four densities $(50,100,200$, and 400 periwinkles $\left.\mathrm{m}^{-2}\right)$ and 5 sizes of cages $(25,50,100,200$, and $400 \mathrm{~cm}^{2}$ ) were used. The number of snails per cage varied from 1 to 8 depending on the density and area combination. Of the possible combinations of density and area, 11 were included (see Table 1). Cages of 400 $\mathrm{cm}^{2}$ proved difficult to maintain, and thus for $400 \mathrm{~cm}^{2}$ cages, only the density treatment of 50 periwinkles $\mathrm{m}^{-2}$ was included. The experiment was set up with 5 replicates of each density $\times$ area combination.

Periwinkles were collected, measured and marked on the mornings of 17 and 18 June 1991. The periwinkles were returned to Mackerel Cove and placed in experimental cages on the morning low tide of 18 and 19 June 1991. Cages were placed on the low shore in a linear array. The ordering of treatments was random. Initial shell height was analyzed with analysis of variance to check for unintended biases in assignment of snails to treatments. For example, if a cage were to contain larger than average snails, then the observed growth response would show not only a density effect but also a body size effect. The experiment ran for $54 \mathrm{~d}$, and the periwinkles were collected and measured on 11 and 12 August 1991.

Data on final shell height and growth were analyzed by analysis of covariance to control for variation in initial shell height. The main effects were density and area, and missing combinations required the use of Type IV sums of squares (see SAS Institute 1989). The variables of interest were shell height and growth at the lip, and the covariate in both analyses was initial shell height. Regressions as part of the ANCOVAs were done to test for linear responses to changes in densities (for methods see Sokal \& Rohlf 1995, p. 521-531). I used only 1 periwinkle from each cage because the growth rates of individual snails within a cage can be correlated (i.e. a form of pseudoreplication: see Hurlbert 1984), and correlated responses can cause a mis-estimation of the effect of the covariate. The initial shell heights of the snails chosen were as similar as possible, but not identical, thus requiring the use of ANCOVA. The data did not require transformation, and tests of homogeneity of slopes were not significant.

1992 competition experiment. The repeatability of the 1991 results was tested by a second experiment in 1992. Based on results from the 1991 experiment, only the effects of density were examined in 1992. I used $100 \mathrm{~cm}^{2}$ cages and 3 densities $\left(100,200\right.$, and $400 \mathrm{~m}^{-2}$ ) with 5 replicates of each. The initial shell height of the snails was controlled experimentally by only using snails between 14 and $16 \mathrm{~mm}$. Snails were collected on 16 June 1992, marked on the lip, and returned to the shore on 17 June 1992. Cages were arranged in linear fashion along the shore, and the ordering of treatments was random. The experiment ran for $38 \mathrm{~d}$ and was terminated on 31 July. The analysis was a nested analysis of variance, with snails nested within cages and cages nested within levels of the density treatment. The mean square of density effect was tested over the mean square of cages. This test is equivalent to 1-way ANOVA using the weighted averages per cage as the variate, and avoids the problem of correlated individual responses within each cage. Regressions were also run to test for linear effects of density. The data did not require transformation.

Growth of free-ranging periwinkles in 1991 and 1992. In the process of setting up the experiments in 1991 and 1992, a small number of snails were marked but not used in the experiments. These individuals were used to provide an independent estimate of growth under field conditions. The periwinkles were released at the time the experiments were started, and the study site was searched for these marked individuals at the termination of each experiment. The number of released snails was not noted in either year, but was in the order of 20 to 50 snails $\mathrm{yr}^{-1} ; 2$ snails were recovered in 1991, and 7 in 1992. Shell height and growth at the lip were measured.

1994 experiment: effect of scavenging on growth. The possibility of scavenging in Littorina littorea and its effects on growth were investigated by providing dead mussels to snails held in cages. Snails were held in $200 \mathrm{~cm}^{2}$ cages with 4 snails cage $^{-1}$ (density = $200 \mathrm{~m}^{-2}$ ). In half the cages, each cage contained 2 live mussels; in the other half, each cage contained 2 dead 
Table 1. Littorina Littorea. Number of snails per cage and replicates in each analysis of the 1991 experiment. np: combinations not possible (e.g. a $25 \mathrm{~cm}^{2}$ cage at a density of 200 periwinkles $\mathrm{m}^{-2}$ would require 0.5 snails per cage); numbers in parentheses: number of replicates; the first number is the number of replicates for the analysis of final height, the second the number for the analysis of lip growth

\begin{tabular}{|lcccc|}
\hline $\begin{array}{l}\text { Area of cage } \\
\left(\mathrm{cm}^{2}\right)\end{array}$ & 50 & 100 & 200 & 400 \\
\hline 25 & $\mathrm{np}$ & $\mathrm{np}$ & $\mathrm{np}$ & $1(4,3)$ \\
50 & $\mathrm{np}$ & $\mathrm{np}$ & $1(5,5)$ & $2(3,3)$ \\
100 & $\mathrm{np}$ & $1(5,5)$ & $2(5,5)$ & $4(5,5)$ \\
200 & $1(5,5)$ & $2(5,5)$ & $4(5,5)$ & $8(4,4)$ \\
400 & $2(2,2)$ & & & \\
\hline
\end{tabular}

mussels with cut adductor muscles. The 2 treatment cages were paired and placed less than $1 \mathrm{~m}$ apart. There were 8 blocks of paired treatments, and blocks were set at least $3 \mathrm{~m}$ apart. Snails were collected on 20 June 1994, marked, measured, and placed into the cages on 21 and 22 June 1994. The condition of the mussels and location of snails were monitored after 1 tidal cycle, and subsequently on 26 June and 9, 11, 18, 24 , and 27 July 1994. In cages with live mussels, mussels that died were replaced, and in cages with dead mussels, mussels were replaced if no flesh remained. The experiment ran for $57 \mathrm{~d}$ and ended on 17 August 1994. Shell height and shell growth were analyzed with randomized-block ANOVAs. Data did not require transformation.

To evaluate if Littorina littorea were attracted to dead mussels, the position of the snails on 26 June 1994 was also analyzed using ANOVA. Data were expressed as the proportion of snails touching the mussels, arcsine-transformed, and analyzed using a randomized-block ANOVA. Observations of the snails' positions on other dates were not analyzed because the rate of loss of mussel tissue and live mussels differed among cages; thus all cages were not handled in an identical manner after 24 June.

\section{RESULTS}

\section{Field observations}

Fewer periwinkles occurred on cobble than on bedrock (cobble average $=255 \mathrm{~m}^{-2}$; bedrock average $=$ $\left.343 \mathrm{~m}^{-2}\right)$, but the difference was not significant $\left(F_{(1,18)}=\right.$ $4.09 ; \mathrm{p} \leq 0.06)$. There was also no significant difference among quadrats nested within type of surface $\left(F_{(18,60)}=\right.$ $0.91 ; \mathrm{p} \leq 0.57$; error mean square $=4.14)$. The overall average density equaled $299 \mathrm{~m}^{-2}(\mathrm{SD}=205 ; \mathrm{n}=80)$.

\section{1 competition experiment}

Data from several of the cages were not used in some analyses because of escapes and intrusions (Table 1). A total of 7 cages were dropped from the analyses of final height and growth because of escapes by 1 or 2 periwinkles from 3 cages, invasions by 1 or 2 limpets into 2 cages, and both escapes and invasions in 1 cage. One additional cage was dropped from the analysis of lip growth because of loss of paint marks.

Analysis of variance of initial shell height showed no effect of density, area, or the interaction of density and area. The overall initial height was $14.0 \mathrm{~mm}(\mathrm{SD}=0.97$; $\mathrm{n}=48$, range: 11.8 to $16.4 \mathrm{~mm}$.

For the analyses of covariance of final height and lip growth, the effect of density was significant, but the effects of area and of the density by area interaction were not (Table 2). Snails were highly variable in growth, and the ranges of individual changes in shell height and growth at the lip, unadjusted for initial shell height, were 0.0 to $3.6 \mathrm{~mm}$ and 0.3 to $7.6 \mathrm{~mm}$ per $6 \mathrm{wk}$, respectively. In spite of the variation in growth, an increase in density clearly depressed growth (Figs. 1 \& 2 ), and most of the variation due to density could be explained by a linear decline with increasing density (98\% of the sums of squares for final height and $90 \%$ for growth at the lip edge).

The periwinkles chosen for analysis did not appear to differ from the total pool of experimental snails,

Table 2. Littorina Littorea. Analyses of covariance for 1991 data on final shell height and growth increment at shell lip. Covariate was initial shell height $(\mathrm{mm})$. Data did not require transformation. Analysis is of growth data on growth increment over the course of the experiment (i.e. $\mathrm{mm}$ per $54 \mathrm{~d}){ }^{* * *} \mathrm{p}<0.0001$; ns: not significant

\begin{tabular}{|c|c|c|c|c|c|c|c|c|}
\hline \multirow[t]{2}{*}{ Source of variation } & \multicolumn{4}{|c|}{ Final height } & \multicolumn{4}{|c|}{ Growth at lip edge } \\
\hline & $\mathrm{df}$ & SS & $F$ & $\mathrm{p}$ & df & SS & $F$ & $\mathrm{p}$ \\
\hline Density & 3 & 17.741 & 13.38 & $* * *$ & 3 & 130.183 & 11.58 & $* * *$ \\
\hline Linear regression & 1 & 17.450 & 39.48 & $* * *$ & 1 & 116.543 & 31.12 & $* * *$ \\
\hline Area & 4 & 0.950 & 0.54 & ns & 4 & 4.655 & 0.31 & ns \\
\hline Density $\times$ Area & 3 & 0.296 & 0.22 & ns & 3 & 6.003 & 0.51 & ns \\
\hline Initial length & 1 & 25.886 & 58.57 & $* * *$ & 1 & 3.941 & 1.05 & $\mathrm{~ns}$ \\
\hline Error & 36 & 15.912 & & & 35 & 131.117 & & \\
\hline
\end{tabular}




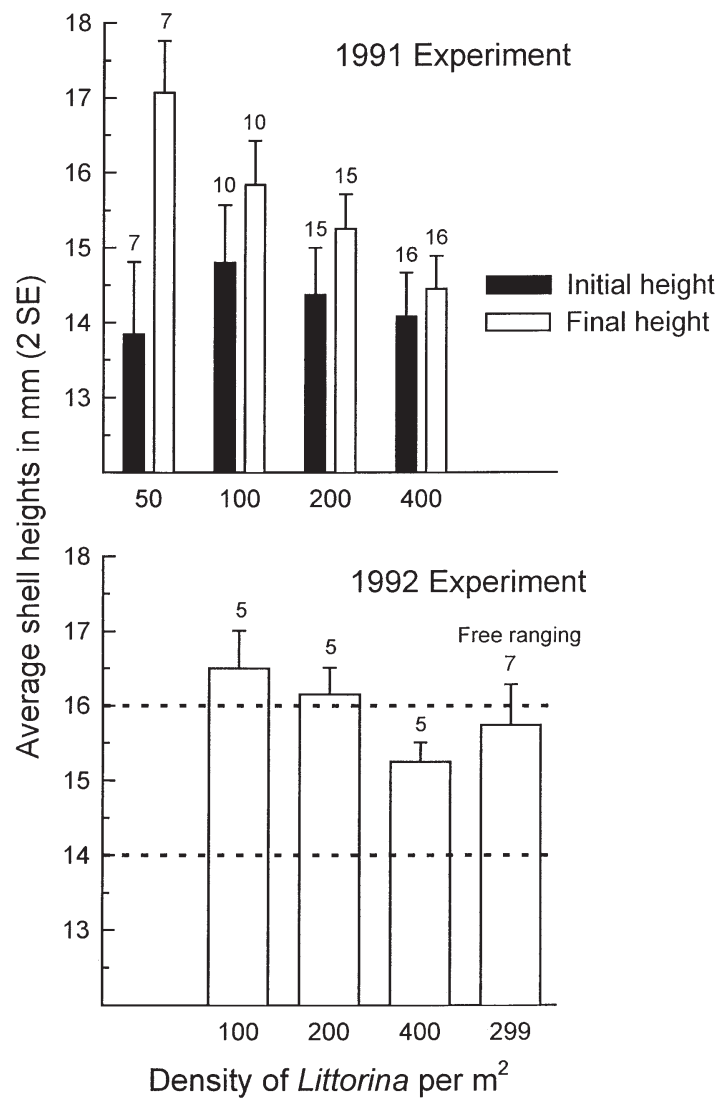

Fig. 1. Littorina Littorea. Average shell heights of periwinkles in the 1991 and 1992 experiments; analysis of data is given in Tables 2 \& 3 . The 1991 averages for final height are least-squared means and adjusted for initial shell height (SAS Institute 1989). Numbers above the standard error bars are sample sizes, which equal the number of cages; calculations of the standard errors for 1992 experiment are based on mean square of cage within density; dotted lines on the graph for the 1992 experiment show the range of initial shell heights; density (299) for the free-ranging snails is the estimated field density of the periwinkles

although the data were not analyzed statistically (Fig. 3). The standard deviations and ranges of the subset tend to be smaller than the total set, reflecting efforts to select individuals of similar initial height for the analyses.

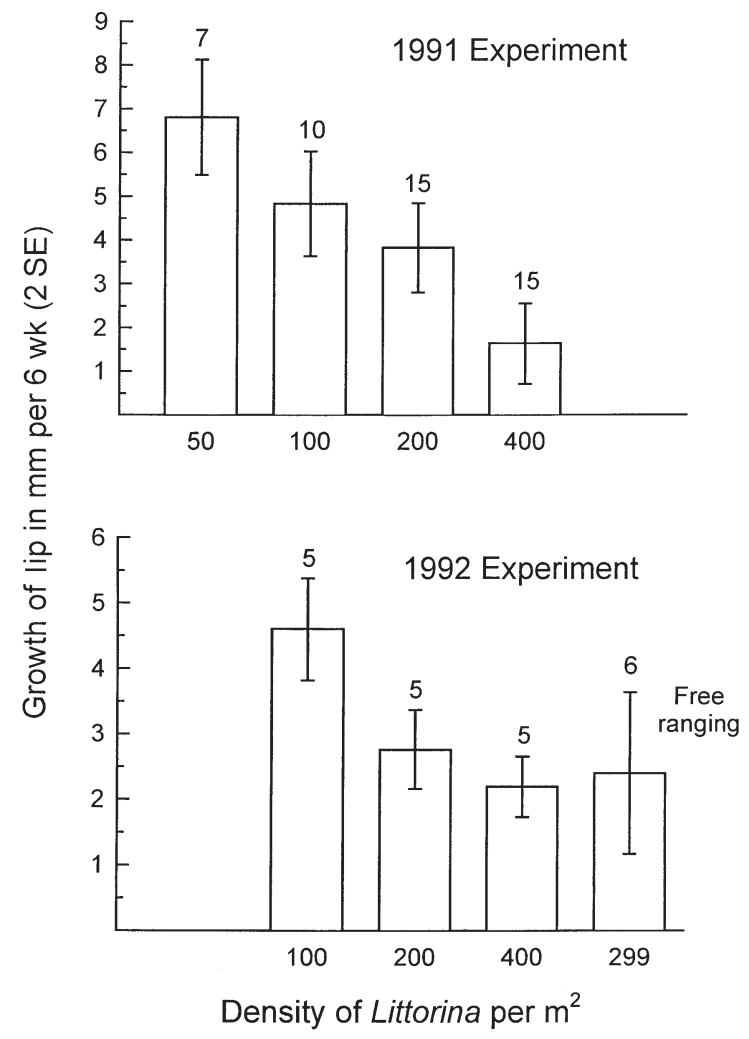

Fig. 2. Littorina Littorea. Average growth at the shell lip of periwinkles in the 1991 and 1992 experiments; analysis of data is given in Tables $2 \& 3$. The 1991 averages for final height are adjusted for initial shell height. Numbers above the standard error bars are sample sizes; density (299) for the free-ranging snails is the estimated field density of the periwinkles

\section{2 competition experiment}

Analyses showed a significant effect of density on growth (Table 3, Figs. $1 \& 2$ ). Final shell height and growth at the shell lip declined with increasing density in a linear fashion. Linear regression accounted for $96 \%$ of the sums of squares for growth at the lip, although snails held at densities of 200 and $400 \mathrm{~m}^{-2}$ showed a similar increase of ca. $2.4 \mathrm{~mm}$ (Fig. 2).

Table 3. Littorina Littorea. Nested analyses of variance for 1992 data on final shell height and growth increment at shell lip. Data did not require transformation. Data for growth increment analysis are in $\mathrm{mm}$ per $38 \mathrm{~d}$, i.e. the duration of the experiment. ${ }^{*} \mathrm{p}<0.05 ;{ }^{* *} \mathrm{p}<0.001$; ns: not significant

\begin{tabular}{|c|c|c|c|c|c|c|c|c|}
\hline \multirow[t]{2}{*}{ Source of variation } & \multicolumn{4}{|c|}{ Final height } & \multicolumn{4}{|c|}{ Growth at lip edge } \\
\hline & df & SS & $F$ & $\mathrm{p}$ & df & SS & $F$ & $\mathrm{p}$ \\
\hline Density & 2 & 9.008 & 13.81 & ** & 2 & 17.535 & 11.45 & ** \\
\hline Linear regression & 1 & 7.457 & 22.87 & $* *$ & 1 & 16.749 & 21.87 & ** \\
\hline Cages within Density & 12 & 3.913 & 0.65 & ns & 12 & 9.192 & 3.21 & * \\
\hline Error & 20 & 10.037 & & & 14 & 3.346 & & \\
\hline
\end{tabular}




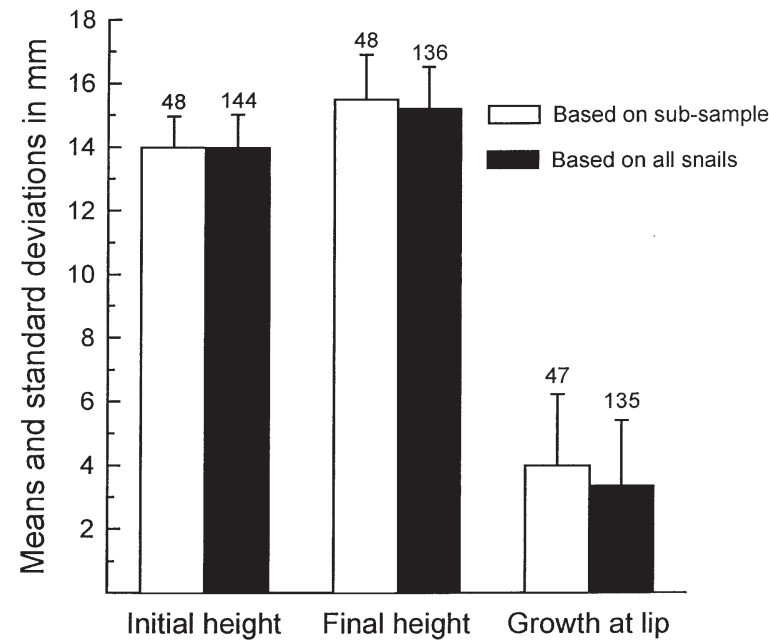

Fig. 3. Littorina Littorea. Average shell heights and growth rates of all periwinkles held in cages for the 1991 experiment and of the sub-sample used in the analyses. Growth averages are rates per $6 \mathrm{wk}$; averages for final shell height and growth are not adjusted for initial height. Numbers above the standard deviation bars are sample sizes

\section{Growth of free-ranging periwinkles in 1991 and 1992}

In 1991, 2 of the released snails were found on 12 August. Both snails had the original paint mark on the growing edge of the lip, and 1 retained its identification number. The initial height, final height, and growth rate at the lip edge of the identified snail were 13.6, 14.2 and $2.0 \mathrm{~mm}$ per $6 \mathrm{wk}$, respectively. The final height and lip of the unidentified snail were 13.9 and $3.3 \mathrm{~mm}$ per $6 \mathrm{wk}$, respectively.

In 1992, 7 snails were recovered on 31 July. All carried an identification number, and 6 of the 7 retained their paint marks. These snails grew at rates nearly identical to those kept in cages, with an average final height of $15.7 \mathrm{~mm}$ and an average growth at the lip of $2.4 \mathrm{~mm}$ per $6 \mathrm{wk}$. The average field density was $299 \mathrm{~m}^{-2}$, which places the growth rates of these freeranging snails within the rates seen in the experiment (see Figs. 1 \& 2).

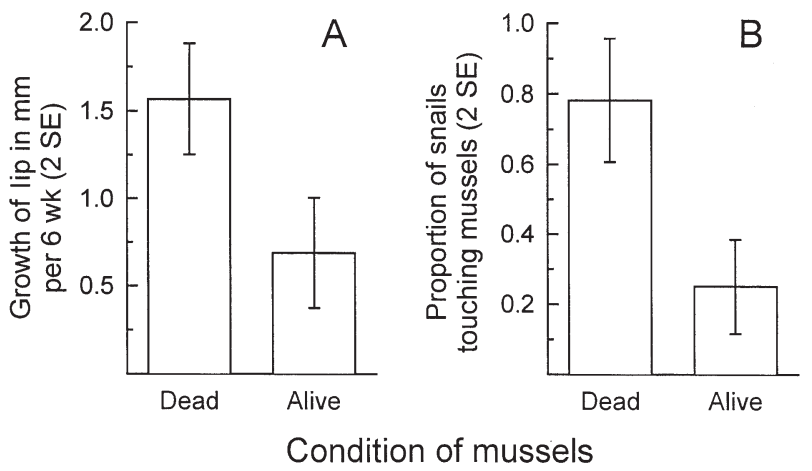

Fig. 4. Littorina Littorea. Average growth at the shell lip and position of periwinkles in the presence of mussel tissue (1994 experiment). Periwinkles were caged with either freshly killed (Dead) or live (Alive) mussels. For proportions, the averages and standard errors are calculated using untransformed data; sample size is 8 for all treatment levels; analysis of data is given in Table 4

\section{4 experiment: effect of scavenging on growth}

Periwinkles added significantly more material at the lip of the shell when provisioned with mussel tissue (Table 4; Fig. 4). Analyses showed no significant effect of treatment on either the initial or final shell height (Table 4). Average shell height was $15.3 \mathrm{~mm}$ at the beginning of the experiment and $15.7 \mathrm{~mm}$ at the end of the experiment. Dead mussels were attractive to periwinkles (Fig. 4): $4 \mathrm{~d}$ after the start of the experiment, roughly 3 out of the 4 snails were found on the valves of the dead mussels and 1 out of the 4 on the valves of the live mussels. Throughout the experiment, the periwinkles in the cages with dead mussels were usually found on the interior of the valves on the remaining flesh of the mussels.

\section{DISCUSSION}

Growth of caged snails declined due to intraspecific effects of density and matched the growth of freeranging individuals at a comparable density. Scaveng-

Table 4. Littorina Littorea. Analyses of data from 1994 experiment. ANOVA of proportion of snails touching mussels was done on arcsine-transformed data; ANCOVAs of final shell height and growth at lip edge used untransformed data. Analysis is of growth data on growth increment over the duration of the experiment (i.e. mm per $57 \mathrm{~d}$ ). Covariate was initial shell height in mm. ${ }^{*} \mathrm{p}<0.05 ;{ }^{* *} \mathrm{p}<0.01$; ns: not significant

\begin{tabular}{|c|c|c|c|c|c|c|c|c|c|c|c|c|}
\hline \multirow[t]{2}{*}{ Source of variation } & \multicolumn{4}{|c|}{$\begin{array}{c}\text { Proportion of snails touching } \\
\text { mussels }\end{array}$} & \multicolumn{4}{|c|}{ Final height } & \multicolumn{4}{|c|}{ Growth at lip edge } \\
\hline & $\mathrm{df}$ & SS & $F$ & $\mathrm{p}$ & df & SS & $F$ & $\mathrm{p}$ & df & SS & $F$ & $\mathrm{p}$ \\
\hline Treatment & 1 & 2.073 & 14.36 & $* *$ & 1 & 0.141 & 1.08 & ns & 1 & 4.633 & 14.06 & ** \\
\hline Block & 7 & 0.600 & & & 7 & 0.941 & & & 1 & 11.239 & & \\
\hline Initial length & & & & & 1 & 0.051 & 0.76 & ns & 1 & 1.912 & 5.80 & * \\
\hline Residual & 7 & 1.011 & & & 6 & 0.408 & & & 6 & 1.977 & & \\
\hline
\end{tabular}


ing by periwinkles also appears to be an important factor in growth, and the consumption of mussel tissue nearly doubles the rate of shell growth. In the 1991 experiment, there was over a 4 -fold decline in growth due to the effect of density. Snails that were 11.8 to $16.4 \mathrm{~mm}$ in shell height and held at a density of $50 \mathrm{~m}^{-2}$ added an average of $6.8 \mathrm{~mm}$ of shell at the lip per $6 \mathrm{wk}$ and those held at $400 \mathrm{~m}^{-2}$ added $1.6 \mathrm{~mm}$ per $6 \mathrm{wk}$. Most of the variation in growth can be explained as a linear function of density. In the 1992 experiment, snails, which were 14 to $16 \mathrm{~mm}$ in shell height, grew at similar rates to those in the 1991 experiment. For example, snails at densities of $100 \mathrm{~m}^{-2}$ grew at the rate of $4.6 \mathrm{~mm}$ per $6 \mathrm{wk}$ in 1992 versus $4.8 \mathrm{~mm}$ per $6 \mathrm{wk}$ in 1991 .

Size of the cage had no significant effect on the rate of growth in 1991, and there was no evidence of caging artifacts. The logic of using cages of different sizes to detect caging artifacts was based on 2 observations. First, periwinkles move non-randomly (Petraitis 1982) and appear to concentrate their foraging near to the edges of cages (pers. obs.); thus, the snails could be competing for space near the edge of the cage, and snails in larger cages (i.e. less circumference per unit of area) might grow more slowly. Secondly, cage size itself could alter consumption rates of foragers and renewal rates of resources (Quinn \& Keough 1993, Mac Nally 1997). Mac Nally's simulations suggest that consumption rates will usually increase with cage dimensions; if this were the case, then snails in larger cages should have shown greater rates of growth. The 1991 experiments showed neither an increase nor a decline in growth rates as a function of cage size.

The significant effects of intraspecific density on growth rates were not an artifact of using unusually high densities in the experimental treatments. The experimental densities were comparable to those seen in the field. The field density of Littorina littorea was $299 \mathrm{~m}^{-2}\left(\mathrm{SD}=205 \mathrm{~m}^{-2}\right)$, which is similar to other values reported in the literature (McQuaid 1996). The smallest experimental density (50 snails $\mathrm{m}^{-2}$ ), is equivalent to $1.22 \mathrm{SD}$ below the average of 299 snails $\mathrm{m}^{-2}$ and the largest experimental density (400 snails $\mathrm{m}^{-2}$ ) is equivalent to $0.50 \mathrm{SD}$ above the average. The range of experimental densities would encompass $58 \%$ of the field observations (assuming normally distributed data and based on values in Table 11 of Rohlf \& Sokal 1981). Thus, the treatment levels used in the 1991 and 1992 experiments reflect densities typically seen in the field.

Other than the results reported here, there have been no experimental studies of the effects of intraspecific competition on Littorina littorea. Competition has been reasonably well studied in gastropods, but most of the work has been done on limpets (e.g. see reviews of Underwood 1979, Branch 1984, McQuaid 1996). Intraspecific effects have been shown in neritid snails (Un- derwood 1976, 1978), trochid snails (Branch \& Branch 1981, Quinn \& Ryan 1989, Schmitt 1996) and littorinid snails (Stiven \& Kuenzler 1979, Underwood 1978, 1984a,b, Chow 1989). Nearly all of these studies involved competitive effects on mortality and biomass rather than changes in shell size, but (like my results) most studies, report relatively large intraspecific effects.

My estimates of rates of growth are consistent with the few published data on Littorina littorea. While L. littorea has been widely studied, there are only 5 reports that provide estimates of growth that can be easily compared to my results. Two of the studies (Williams 1964, Chase \& Thomas 1998) used analysis of shifts in the modal or average shell height of free-ranging periwinkles to estimate growth. Williams reported growth rates equivalent to 0.17 to $0.27 \mathrm{~mm}$ per $6 \mathrm{wk}$ for snails 11 to $18 \mathrm{~mm}$ in shell height. Williams provided no data on densities, but from his sampling information it appears the density was approximately $107 \mathrm{~m}^{-2}$. Calculations based on data from Chase \& Thomas (their Table 1 \& Fig. 2) give a larger estimate: an average rate of $2.4 \mathrm{~mm}$ per $6 \mathrm{wk}$ for periwinkles with an initial shell height of 10.6 to $17.2 \mathrm{~mm}$.

Three studies used individually marked periwinkles (Ekaratne \& Crisp 1984, Behrens Yamada 1987, Gardner \& Thomas 1987). Gardner \& Thomas (their Tables 1 and 2) reported changes in average heights of 5.4 and $6.2 \mathrm{~mm}$ per $150 \mathrm{~d}$ for snails with initial modal heights of 12.3 and $17.9 \mathrm{~mm}$, respectively. The average field density was about $350 \mathrm{~m}^{-2}$. Their rates are equivalent to growth rates of 1.5 to $1.7 \mathrm{~mm}$ per $6 \mathrm{wk}$. They also provided some data on growth at the shell lip (their Table 3), and from these data, I estimated an average rate of $3.1 \mathrm{~mm}$ per $6 \mathrm{wk}$ (range: 2.0 to $4.1 \mathrm{~mm}$ per $6 \mathrm{wk}$ ). Behrens Yamada provided a number of estimates for periwinkles collected from 4 locations and released in a single area. She found little evidence for differences among the populations, and the average rate of growth was $1.03 \mathrm{~mm}$ per $6 \mathrm{wk}$ (based on data in her Table 3 and weighted by the reported sample sizes). The snails ranged from 5 to $15 \mathrm{~mm}$ in shell height. Finally, Ekaratne \& Crisp looked at micro-growth lines at the shell lip. They held periwinkles in cages and provided abundant food. The periwinkles added shell at the lip at average rates of $3.8 \mathrm{~mm}$ per $6 \mathrm{wk}$ (data from their Table 2A; growth over 30 tidal immersions) and $7.8 \mathrm{~mm}$ per $6 \mathrm{wk}$ (data from their Table 6; growth over $149 \mathrm{~d}$ ).

The most interesting observation is that periwinkles consume animal tissue. Scavenging by Littorina littorea has been reported (Hayes 1929, Fenske 1997), but there are no reports of the effects of scavenging on growth. Several lines of evidence indicate that periwinkles in the 1994 experiment were consuming animal tissue and not merely harvesting the flora that had colonized the tissue. Firstly, the periwinkles in cages with dead mus- 
sels moved quickly onto the mussel tissue and remained there as long as tissue was present. The initial movement onto the tissue occurred within 1 tidal cycle. While colonizing flora could have built up within $12 \mathrm{~h}$, I believe the periwinkles were responding to signals from the tissue itself, not from colonizing flora. Secondly, while data on the rate of tissue loss were not taken, it appeared that the amount of mussel tissue declined rapidly when periwinkles were present. Thirdly, the increase in growth rates was dramatic with over a 2-fold increase in 1994 over the rates seen in 1991 and 1992 (Fig. 4). Taking the data together, I believe periwinkles could be active scavengers.

The work reported here may raise more questions than it answers. How common is scavenging by Littorina littorea and what are the potential effects on its population dynamics and community interactions? If scavenging is common, then fecundity and growth of periwinkles may be greatly enhanced by the availability of animal tissue. At the community level, scavenging by a presumed herbivore could affect trophic interactions. For example, it is well known that the stability of food webs depends on the amount of omnivory (Pimm \& Lawton 1977, Menge 1995). If periwinkles commonly scavenge, then the analyses of marine food webs that contain littorinid snails (e.g. Menge 1995) may need to be re-evaluated.

Acknowledgements. I would like to thank Peter Fairweather who, during a visit to my study sites in 1993, made the original observation and suggestion that Littorina littorea may be scavenging animal tissue. Lisa Methratta and 3 anonymous reviewers carefully read the manuscript, and I thank them for their comments.

\section{LITERATURE CITED}

Behrens Yamada S (1987) Geographic variation in the growth rates of Littorina littorea and L. saxatilis. Mar Biol 96: 529-534

Branch GM (1984) Competition between marine organisms: ecological and evolutionary implications. Oceanogr Mar Biol Annu Rev 22:429-593

Branch GM, Branch ML (1981) Experimental analysis of intraspecific competition in an intertidal gastropod, Littorina unifasciata. Aust J Mar Freshw Res 32:573-589

Brenchley GA, Carlton JT (1983) Competitive displacement of native mud snails by introduced periwinkles in the New England intertidal zone. Biol Bull 165:543-558

Chase ME, Thomas MLH (1998) Production and resource allocation in the periwinkle, Littorina littorea (Linnaeus, 1758), on Pendleton Island, New Brunswick. J Shellfish Res 17:937-944

Chow V (1989) Intraspecific competition in a fluctuating population of Littorina plena Gould (Gastropoda: Prosobranchia). J Exp Mar Biol Ecol 130:147-165

Connell JH (1983) On the prevalence and relative importance of interspecific competition: evidence from field experiments. Am Nat 122:661-696
Creese RG, Underwood AJ (1982) Analysis of inter- and intraspecific competition amongst intertidal limpets with different methods of feeding. Oecologia 53:337-346

Ekaratne SUK, Crisp DJ (1984) Seasonal growth studies of intertidal gastropods from shell micro-growth band measurements, including a comparison with alternative methods. J Mar Biol Assoc UK 64:183-210

Fenske C (1997) The importance of intraspecific competition in a Littorina littorea population in the Wadden Sea. Hydrobiologia 355:29-39

Fish JD (1972) The breeding cycle and growth of open coast and estuarine populations of Littorina littorea. J Mar Biol Assoc UK 52:1011-1019

Gardner JPA, Thomas MLH (1987) Growth and production of a Littorina littorea (L.) population in the Bay of Fundy. Ophelia 27:181-195

Gurevitch J, Morrow LL, Wallace A, Walsh JS (1992) A metaanalysis of competition in field experiments. Am Nat 140: $539-572$

Haven SB (1973) Competition for food between the intertidal gastropod Acmaea scabra and Acmaea digitalis. Ecology 54:143-151

Hayes FR (1929) Contributions to the study of marine gastropods. III. Development, growth and behaviour of Littorina. Contrib Can Biol Fish 4:415-430

Hurlbert SH (1984) Pseudoreplication and the design of ecological field experiments. Ecol Monogr 54:187-211

Lubchenco J (1978) Plant species diversity in a marine intertidal community: importance of herbivore food preference and algal competitive abilities. Am Nat 112:23-39

Mac Nally R (1997) Scaling artefacts in confinement experiments: a simulation model. Ecol Model 99:229-245

McQuaid CD (1996) Biology of the gastropod family Littorinidae. II. Role in the ecology of intertidal and shallow marine ecosystems. Oceanogr Mar Biol Annu Rev 34:263-302

Menge BA (1995) Indirect effects in marine rocky intertidal interaction webs - patterns and importance. Ecol Monogr 65:21-74

Moore HB (1937) The biology of Littorina littorea. Part I. Growth of the shell and tissues, spawning, length of life and mortality. J Mar Biol Assoc UK 21:721-742

Ortega S (1985) Competitive interactions among tropical intertidal limpets. J Exp Mar Biol Ecol 90:11-25

Petraitis PS (1982) Occurrence of random and directional movements in the periwinkle, Littorina littorea. J Exp Mar Biol Ecol 59:207-217

Petraitis PS (1983) Grazing patterns of the periwinkle and their effect on sessile intertidal organisms. Ecology 64: $512-533$

Petraitis PS (1987) Factors organizing rocky intertidal communities of New England: herbivory and predation in sheltered bays. J Exp Mar Biol Ecol 109:117-136

Petraitis PS (1989) Effects of the periwinkle Littorina littorea (L) and of intraspecific competition on growth and survivorship of the limpet Notoacmea testudinalis (Müller). J Exp Mar Biol Ecol 125:99-115

Petraitis PS (1990) Direct and indirect effects of predation, herbivory and surface rugosity on mussel recruitment. Oecologia 83:405-413

Petraitis PS (1991) Recruitment of the mussel Mytilus edulis L. on sheltered and exposed shores in Maine, USA. J Exp Mar Biol Ecol 147:65-80

Pimm SL, Lawton JH (1977) Number of trophic levels in ecological communities. Nature 268:329-331

Quinn GP, Keough MJ (1993) Potential effect of enclosure size on field experiments with herbivorous intertidal gastropods. Mar Ecol Prog Ser 98:199-201 
Quinn GP, Ryan NR (1989) Competitive interactions between two species of intertidal herbivorous gastropods from Victoria, Australia. J Exp Mar Biol Ecol 125:1-12

Rohlf FJ, Sokal RS (1981) Statistical tables, 2nd edn. WH Freeman, San Francisco

SAS Institute (1989) SAS/STAT user's guide; Version 6, Vol 2, 4 th edn. SAS Institute, Cary, NC

Schmitt RJ (1996) Exploitation competition in mobile grazers: trade-offs in use of a limited resource. Ecology 77:408-425

Sokal RS, Rohlf FJ (1995) Biometry: the principles and practice of statistics in biological research, 3rd edn. WH Freeman, New York

Stiven AE, Kuenzler EJ (1979) The response of two salt marsh molluscs, Littorina irrorata and Geukensia demissa, to field manipulations of density and Spartina litter. Ecol Monogr 49:151-171

Underwood AJ (1976) Food competition between age-classes in the intertidal neritacean Nerita atramentosa Reeve (Gastropoda: Prosobranchia). J Exp Mar Biol Ecol 23:145-154

Underwood AJ (1978) Experimental evaluation of competition between 3 species of intertidal prosobranch gastropods. Oecologia 33:185-202

Underwood AJ (1979) The ecology of intertidal gastropods. Adv Mar Biol 16:111-210

Editorial responsibility: Ronald Karlson (Contributing Editor), Newark, Delaware, USA
Underwood AJ (1980) The effects of grazing by gastropods and physical factors on the upper limits of distribution of intertidal macroalgae. Oecologia 33:185-202

Underwood AJ (1984a) Microalgal food and the growth of the intertidal gastropods Nerita atramentosa Reeve and Bembicium nanum (Lamarck) at 4 heights on a shore. J Exp Mar Biol Ecol 79:277-291

Underwood AJ (1984b) Vertical and seasonal patterns in competition for microalgae between intertidal gastropods. Oecologia 64:211-222

Underwood AJ (1986) The analysis of competition by field experiments. In: Kikkawa J, Anderson DJ (eds) Community ecology: pattern and process. Blackwell Scientific, Melbourne, p 240-268

Underwood AJ, Jernakoff P (1981) Interactions between algae and grazing gastropods in the structure of a lowshore algal community. Oecologia 48:221-233

Vermeij GJ (1980) Gastropod shell growth rate, allometry and adult size. In: Rhoads DC, Lutz RA (eds) Skeletal growth of aquatic organisms. Plenum Press, New York, p 379-394

Williams EE (1964) The growth and distribution of Littorina littorea (L.) on a rocky shore in Wales. J Anim Ecol $337: 413-432$

Submitted: September 27, 2000; Accepted: February 13, 2002 Proofs received from author(s): May 28, 2002 